\title{
Beauty and battle: How the Spirit is moving and operating in the Reformed Churches of the Netherlands
}

\author{
Author: \\ J. (Hans) Kommers ${ }^{1}$ \\ Affiliation: \\ ${ }^{1}$ Faculty of Theology, \\ North-West University, \\ Potchefstroom Campus, \\ South Africa \\ Correspondence to: \\ Hans Kommers \\ Email: \\ j.kommers777@gmail.com \\ Postal address: \\ Operadreef 94, 3845GR \\ Harderwijk, the Netherlands \\ Dates: \\ Received: 04 Nov 2009 \\ Accepted: 24 Aug 2010 \\ Published: 13 Dec. 2012 \\ How to cite this article: \\ Kommers, J., 2012, 'Beauty \\ and battle: How the Spirit is \\ moving and operating in the \\ Reformed Churches of the \\ Netherlands', In die Skriflig/ \\ In Luce Verbi 46(2), Art. \\ \#60, 6 pages. http://dx.doi. \\ org/10.4102/ids.v46i2.60 \\ Note: \\ This article was original read \\ as a paper for the Houten \\ Conference in Stellenbosch, \\ 27 August 2009.
}

(C) 2012. The Authors. Licensee: AOSIS OpenJournals. This work is licensed under the Creative Commons Attribution License.
This article discusses how we in the present day hear the sound of the Holy Spirit and where his work can be witnessed in the Reformed Churches of the Netherlands. Mainstream churches have been faced with many challenges during the first decade of the 21st century. Many people have left these churches and have had little contact with its institutions. Is it necessary for them to search for spirituality elsewhere? The author is convinced that the Lord is not bypassing his church. The following question is relevant, In what way is the Spirit working today? This question is urgent, because today there is a renewed search for the reality and power of the Holy Spirit. Within the great and traditional Reformed Churches we hope to see a spiritual renewal. Last year the synod of the Protestant Church in the Netherlands revealed a new vision for mission work, which indicates that the church wants to return to its core function, to reach out to others who do not know the Lord Jesus Christ. Looking forward to the dynamic work of the Holy Spirit in this century, we are already witnessing the beauty of the work of the Holy Spirit, but we have a battle to wage in order not to lose what has been gained.

Grootsheid en stryd: Die dinamiese werking van die Gees in die Gereformeerde Kerke van Nederland. In hierdie artikel word die teenwoordigheid en werking van die Heilige Gees in die Gereformeerde Kerke van Nederland bespreek. Die hoofstroomkerke het met baie uitdagings te kampe gehad tydens die eerste dekade van die 21ste eeu. Baie mense het hierdie kerke verlaat sonder om enige verdere interne kontak daarmee te hê. Was dit vir hulle nodig om elders na spiritualiteit te gaan soek? Die outeur is daarvan oortuig dat die Here nie sy kerk verlaat het nie. Die volgende vraag is relevant: Op watter wyse werk die Gees vandag? Hierdie vraag is belangrik, aangesien daar ' $n$ hernude soeke is na die wese en krag van die Heilige Gees. Binne die groot tradisionele gereformeerde kerke hoop en verwag 'n mens om spirituele herlewing te sien. Die sleutelplan wat die Protestantse Kerk van Nederland (PKN) se sinode in 2009 bekendgestel het vir die oplewing in sending, wys dat die kerk wil terugkeer na sy kerntaak. 'n Toekomsblik op die dinamiese werk van die Heilige Gees in hierdie eeu dui op die grootsheid van die werk van die Heilige Gees tot dusver en dat ons die stryd moet verskerp om nie te verloor wat ons tans het nie.

\section{Introduction}

\section{Mainstream religion and the search for spirituality}

The Bible says, 'Nothing is hidden from the Spirit, not even "the deep things and thoughts of God"' (cf. 1 Cor 2:10-11). However, the subject of determining how the Spirit moves and operates is a very difficult one. In order to understand this, one has to be both a seer and a prophet. Such a person has to be someone who considers quality more important than quantity. When talking about the Spirit and how He is moving and operating in the Reformed Churches in the Netherlands and elsewhere, it is strongly felt that the real influence of the Reformed Churches lies in direct proportion to the depth of its spiritual life. Today, in the search for spirituality as 'the transforming power of God's Spirit in the Christian life' (Benedetto, Guder \& Mc Kim 1999:306), we 'hear a sound like the blowing of a violent wind' (Ac 2:32), in the similar manner that people in Jerusalem at Pentecost experienced it. We cannot determine the phenomenon exactly, but just as it took complete possession of those present in Jerusalem ${ }^{1}$ at the time, we too are beginning to experience its effects in our modern world. Although what happened at Pentecost on that day in Jerusalem (Ac 2) was really a unique event, we see further on in Acts that after intense prayer believers 'were filled with the Holy Spirit' (Ac 4:31). Peter was still speaking 'when the Holy Spirit came upon all who were listening to the message' (Ac 10:44). This indicates that the occurrences at Pentecost have extended into the lives of people throughout history and into the present day as the Holy Spirit continues to reveal himself.

1.Van Eck (2003:56) refers here to Ezekiel, where the prophet in chapter one shows how wind and fire as indications of the divine that takes possession of the people. 'Het is de Geest die de wereld en de mensen die daarin leven in al hun concreetheid vervult.' 
We attempt to hear the sound of the Spirit today by demonstrating the size of our members or through the vast machinery of the synod, churches, congregations and agencies. However, as churches we have to face being crossexamined by the Word of God. It may be painful, but it is health-giving. Biblically, the word correcting as a verb means to restore. It contains the Greek root from which we have the word orthodontics. It is a healing term, not a harmful one. The Spirit heals and restores broken and twisted lives. In the book of Acts, ${ }^{2}$ as well as in the work of the Spirit today, people's lives are being transformed and filled. 'Now let it work', Bruce (1981:61) exclaimed when he talked about the coming and the fullness of the Spirit, which the followers of Jesus received from Pentecost onwards. For him, it was the means by which the kingdom of God was launched with power. 'The power from on high has been bestowed; now let it work!' There is no master key through with which we can discern the work of the Spirit, but we hear the sound! We thank God that $\mathrm{He}$ is raising up in many places and congregations those whose spiritual life is clearly evident.

In this the first decade of the 21st century, spiritual matters are openly discussed and even advertised. On one of the commercial billboards in a major city in the Netherlands, it said: 'If you want to have a spiritual experience, please call ...' Special magazines are dedicated to spirituality; even courses can help you to discover your own spirituality. People long for a 'fundamental life orientation to give sense to the individual and collective experience and determine their deeds' (Douma 2000:74). We are longing for the experience of a deep relationship with God and to see the work of the Spirit blowing through our personal lives and congregations. For the churches in the 21st century it can no longer be business as usual. As Van der Walt (2009:267) says: 'They face a simple choice. $^{3}$

As churches we are not of this world, but because we are in it we cannot withdraw from the developments in our culture. The culture in the developing world is thoroughly atheistic. This culture grew originally from Christian roots. The church - including the Protestant Churches - had for centuries shaped the culture of the Western world. The world around us was understood through the story of the Bible as a whole. As our society has become more pluralistic, Christian teaching has also become a marginal part of public education or has been excluded altogether. With nostalgia one can say with the prophet Isaiah, 'Where is He who set his Holy Spirit among them?' (Is 63:11). The absence of God and his Spirit is felt. There is no room for boasting; sometimes I think there is ample time for weeping. I agree, it is easy to be overtaken by a spirit of dejection when we are talking about matters of church and belief. The continuation of the church is no longer accepted without question. Even the churches themselves do not provide a positive picture of the state of belief in the modern world.

2. Not inappropriately, the second book of Luke sometimes has been called The Acts of the Holy Spirit (cf. Pierson 1913).

3.This is a refreshing article on the question of what has been occurring in the mainstream religions and their institutions since the 1960 s.
The reunification or unification of the Protestant Church in the Netherlands (PKN) in 2004 was a process that took many years. On the one hand, one could say, 'It's the ultimate vision Jesus had in mind when He talked about "all to be one" (Jn 17:21). On the other hand, it has proved to be a disaster. ${ }^{4}$ What can we assume of the yearly loss of 50 000-60 000 nominal adherents or church members in the PKN. ${ }^{5}$ For the coming years it is expected that about 800 church buildings, either Roman Catholic and/or Protestant, will no longer be needed. Was the unification of the three churches ${ }^{6}$ from the Spirit? Do the churches have life and do they have it more abundantly? How is it that we see so little spiritual life and energy in the new church? To discern how the Spirit moves and operates (the Spirit as the invisible presence of God in this world), it is necessary not to succumb to the trap which we see occurring within certain churches, that is, wrongly classifying things as coming from the Spirit. It is not possible to talk about the work of the Spirit without any reference to Christ, the visible form of God's revelation.

Having said this, currently we are witnessing the widespread influence of the work of the Holy Spirit in congregations and the world. We can see this in our contacts with Eastern Orthodox Churches via the ecumenical movement, in out contacts with Pentecostal Churches in Latin America and, recently, in the Netherlands, as well as in the spiritual crisis occurring in the developed world (ff. Noordegraaf 2009:77).

\section{A renewed focus on mission work}

How does a church communicate what it perceives as its commission? Many people today have no idea what to think when they hear the word God. Man have left God, not for other gods, but for no god! And this has never happened before. Bavinck (1949) said that only the Holy Spirit can convert a nihilist. It is the Holy Spirit who creates receptivity in people. People who are not touched by the Holy Spirit suppress the truth that they are made for God when they hear the sound of his voice. This is the first cornerstone of unbelief (Bavinck 1949:171-180). Christian thinkers are busy establishing the reasonability of Christianity.?

In Reformed Churches one can see the crucial role that proclamation played in the understanding of the church. Today, the stress on proclamation will need to be given substance considering the heavy stress on the accompanying demonstration of the gospel. Proclamation and demonstration need to take on a fresh significance. Whilest there is a need to renew our commitment to proclaim the Word faithfully, there is a greater need to convey the message in acts that express the concrete demonstration of the gospel in our society. Gnanakan (2008:9) says: 'Proclamation is urgent,

4.'This whole process runs the risk of being superficial and unspiritual. [...] People cannot organize a renewal of the church. What have we gained with all our meetings, organisations and decisions?' (Balke 1985:222)

5.In 2008 a total of 58000 left the PKN.

6.The continuation of the Nederlandse Hervormde Kerk, the Gereformeerde Kerken in Nederland and the Evangelisch-Lutherse Kerk in het Koninkrijk der Nederlanden (cf. Protestantse Kerk in Nederland 2003: Article 2, 10).

7.Concider the recent debates in the Netherlands where they questioned the whole concept of creation. 
demonstration is the priority'. In situations such as these, where people have a strong desire to put their plans into action, institutes such as churches can act as a barrier to their fulfilment.

Why is it that to believe without the aid of a church is not an option? One of the biggest challenges today is overdependence on methods, strategies, institutions and technologies for the proclamation of the gospel. The challenge before us is to discern the voice of the Holy Spirit amidst the noise of our histories, cultures and lifestyles. Are not the demons of our times akin to the demon of which Jesus said, 'This kind goes not out, but by prayer and fasting' (Mt 17:21)?

We largely accept the plausibility structure and try to adjust our beliefs to fit with it. But public opinion is not the final word, especially when we observe that the new move towards religiousness disregards the message of the Christian Church and in most cases has nothing or little to do with the Christian faith. We observe amongst us the reality that it is the Spirit who addresses us through the Word of God. Every day I see around me a Christian praxis of belief. We cannot even imagine a way of life in which belief has no transparent role. We can detect beauty when we see how the Spirit is moving and operating in the Reformed Churches of the Netherlands today. In the Protestant Church in the Netherlands there is a renewed mission work spirit which is radiating to the people in the Netherlands. It is a church where worship has once again become the focus. Crucial to this is respect for the Word of God, daily wonder at his grace and passion for the Crucified. As a pastor in a city with about 80000 inhabitants, I see young people weekly, coming together searching for guidance for their spiritual lives. These are people who are confessing the Lord Jesus Christ and whose lives are practically affected by such belief. The Spirit is affecting every aspect of these people's lives.

From synod level to local churches there is a renewed awareness for mission work. The Protestant Church in the Netherlands has revealed their new vision for mission work: ${ }^{8}$ to return to the core business of the church, reaching out to others that do not know the Lord Jesus Christ. We cannot organise a revival, but a new awareness - a cloud as small as a man's hand (1 Ki 18:30) - is a token that the Holy Spirit is at work. For example, in 2004 we received the New Bible Translation (NBV). Within three months nearly 400000 copies had been sold. ${ }^{9}$ One is aware of academic conferences ${ }^{10}$ and initiatives at local level, of which Close or restart is one of the themes. Forum $C$ group wants to connect Christian belief with questions regarding society, culture and personal life. Christians have to be visible in and subservient

8.This initiative is not only focused on mission work, but also on church growth. At the start of the new church in 2004 the main prayer according to the secretary that time, Plaisir (2008:74) was 'Holy Spirit, renew your church' (see www.pkn.nl/ missionair).

9.When in 1637 the new Bible translation (the Statenvertaling) came in use in the Netherlands,twenty years passed before 100000 copies were sold!

10.Areopagus is since 2003 a centre for contextual and missiological preaching. The aim is to teach pastors to address their contemporaries in a convincing manner
with an unpopular message. Areopagus is an initiative of the IZB (Inwendige with an unpopular message. Areopagus is an initiative of the IZB
Zendingsbond). IZB is a league for mission work in the Netherlands. to universities, work and society. One church somewhere in the Netherlands states: 'We rediscover the calling of the church' (Anon 2009a:64). The question the church has had to face is whether to stop, continue or replant? They really had to begin again from zero.

It is of significance that the phenomenon we are seeing occurring within the church does not have its origin in man. We are inclined to attribute it the transforming work of the Spirit of God. In many local churches prayer groups have been formed focusing on God and longing for a renewed outpouring of the Spirit. It is not unusual to see people gathering at six o'clock in the morning to pray - mothers for the school leadership; congregations of elderly people for the youth, et cetera. We hope to see and expect a revival of the great traditional Reformed Churches in the future. 'These traditions will radiate a new expressiveness.' This will not occur in an ex cathedra manner, but in a flexible way. The move will be from doctrine to a real Christian lifestyle. There is a real hunger for transcendent things and for a God who is not waiting till we will act so that the feast can begin. Sermons on a Reformed Church's website in America have a few million downloads a year - more than the Oprah Winfrey show (Anon 2009b:73, 2009c:73; De Korte 2009). People see a possibility in the Netherlands for these kind of churches, especially for churches with a mission work attitude as in some of the new church plantings in the big cities.

These changes sound good; we can detect some beauty. Are these changes caused by the move of the Spirit? When we refer to God's absence in our society, is that not really the result of our absenting ourselves from Him? He is not hiding Himself, but we hustle Him away behind the curtains of our unwillingness (Bavinck n.d.:13). What does it mean when Paul writes:

We are not just battling against flesh and blood, but against the rulers, against the authorities, against the powers of this dark world and against the spiritual forces of evil in the heavenly realms (Eph 6:12)?

In Europe we can see that old heathen roots are sprouting again. Many people have returned to celebrating the pagan religions from the time before Christianity entered Europe: Halloween parties, Valentine's day, cults around Christmas, the revival of Wicca (practicing witchcraft) and interreligious rituals. These people are looking for meaning and cohesion in their vulnerable existence. There is a tremendous decline in membership and a recession in the old churches. The PKN expects that by 2020 church membership will decline by half. Many of those leaving the church say that they are not rejecting God, but they have had enough of the institutional church. It is not that they don't want to hear the gospel preached, but they don't want our gospel preaching!

\section{A deeper spiritual problem}

Perhaps no area of church life is more controversial than that of spiritual warfare. It leaves many in the national church confused. People believe demonic powers do not exist. The questions that arise are complex and difficult. Theological, cultural, practical and historic issues all come into play. Isobel 
Kuhn (quoted by eds. Scott Moreau, Corwin \& McGee 2004:288) says: 'The only person who does not believe that the devil is a person is someone who has never attempted to combat him or his ways.' The biblical evidence is clear, however, that Satan exists and harbours malice and hatred towards all people. The New Testament warnings to humble ourselves before God and be on guard so that we can resist Satan (1 Pt $5: 8-9)$ and stand our ground in the face of his attacks (Eph 6:10-18), make it clear that Christians are not immune to his assaults. We should be more aware and trained in spiritual warfare. Spiritual mapping and strategic-level spiritual warfare are advocated to reach the lost. But there is a deeper spiritual problem. Traditions of belief and confession have authority, but how validly are they functioning? The truth is at times revealed not from a standpoint of full certainty. For example, when thousands of Christians attend charismatic manifestations, like Heaven on Earth, organised by TRIN (Touch, Reach and Impact the Nations), a revival is claimed. At such times we need to ask ourselves: 'Which Jesus are they talking about?' Is this the preaching of another Jesus, and are we receiving another spirit, as Paul writes to the congregation in Corinth (2 Cor 11)?

We are depending too much on our own systems. We have 'hewn out cisterns for ourselves, broken cisterns that can hold no water', as Jeremiah 2:13 says. In the same way Israel did, we trust in jars of clay that our hands have fashioned, only to discover in the heat and the drought of summer that the water has seeped through the cracks, lapped dry by the parched ground. It is the nature of idols, our self-made gods, that they fail completely when people need them and that they leave people with empty hearts and hands.

Spiritual verification in these matters is imperative. During a recent seminar of the reformed churches, one of the participants exclaimed: 'We tried everything, except the Holy Spirit' (eds. Van de Kamp \& Tan 2009:15).

In the old Corinth, people twisted and perverted the personality and character of Jesus by seeing Him as a figure full of power. In Paul's gospel, preaching the Cross is central. Jesus' weakness has an important place in Paul's preaching. The Christians in Corinth wanted to impress other people and they were not willing to focus on imitation and bearing the Cross. They suggested that the battle to bear the Cross was for spiritual losers, who did not care about the triumph of Easter or the day of resurrection. Paul, however, follows the road of weakness. He took the lower road. The way to resurrection is by the Cross and by bearing the Cross.

It is absolutely necessary to distinguish the spirits in our church today. TRIN announces: 'The game is over' for religious systems and structures. Churches are claiming God's blessings, because they believe God wants them to have a successful life and to be prosperous. It is a gospel of health and wealth. This gospel of prosperity is deceptive. We ought not to follow a success-driven Jesus. For Paul this is another Jesus, one who does not exist and never has existed. We ought to follow Christ and not our dreams. It is not wealth which ought to be our focus. Christ gave Paul a 'thorn in the flesh' but God's grace was enough for him (2 Cor 12:7).

What is meant by following Jesus? We know from the Scriptures that Jesus came and lived to bear the Cross. There is no need to be a theologian to know that unpretentious service is the highest glory. Nowadays, some movements, such as TRIN, distort the biblical facts. They are liberal and choose certain parts of Scripture, neglecting the classical reading of the Scriptures, and constructing their own Jesus. ${ }^{11}$ What is happening in our time? Romans 1:18 and 23 provides us with a clear picture. People who do not really believe suppress the truth and live in godlessness and, according to Romans 1:23, 'exchanged the glory of the immortal God for images'. In other words, idols are replacing God. These idols are supposed to give us what only God can give us, namely harmony, joy, inner peace and freedom from feelings of guilt. Ultimately people forfeit the truth for the idol they slavishly adore. In Psalm 115 we see how idolatry works. Everybody lives for something or someone. Psalm 115 says that essentially it is either God or ourselves. Therefore, everybody is a slave. This is a logical conclusion because it is those things which we live for that control our life. The more loyal we are to an idol, the further in our experience we are from the true God. When we honour idols, it controls our lives. Thus, when you lose your idol, you lose yourself.

The Spirit of the living God unmasks this way of life. The Scriptures talk about the struggle between flesh and Spirit. The Spirit comes from above and from history. In other words, the Spirit is connected with the historical Christ and He is God Himself. It is God who works within me, together with the salvation worked by the historical Christ. Van Ruler (1972) states:

In ieder geval: het is wezenlijk voor de structuur van het christelijke geloof, dat het heil niet ligt in en opkomt uit het geleefde leven, de existentie of de wereldwerkelijkheid, maar uit Palestina, uit de geschiedenis naar ons toekomt.[...] Men zal ook de Heilige Geest in eerste aanleg in de werking van deze institutionele momenten moeten zoeken: Hij poneert de Christus, inspireert de Heilige Schrift, zendt de apostelen, schept de traditie, gebruikt de ambten, roept de liturgerende kerk in het aanzijn. [Van Ruler explains here that it belongs to the Christian belief, that our salvation not is in and occurs out of the life we live, the very existence of our reality, but from Palestine, from history it comes to us [...] The Holy Spirit is working when the Word of God is preached. He puts forward the Christ, inspires the Holy Scriptures, is sending the apostles, creates the tradition, uses the functions in the church, calls forward the worshipping congregation'. (pp. 183-184, [author's own translation])

The Holy Spirit has to be proclaimed, not as the mightiest of all the spirits but as the One, sent by the Father and the Son (Ps 104:30). Christ came in the flesh. Looking across the field of the church, I cannot help reciting the words we read in Isaiah 63:11:

Then his people recalled the days of old, the days of Moses and his people. Where is He who brought them through the 11.For further information, see www.heaven-on-earth.nl and www.trin.ni. 
sea, with the shepherd of his flock? Where is he who sent his Holy Spirit amongst them?

Confrontation with the biblical truth leads, when one is honest, to a fracture with the past, to conversion of the lie, to a process of radical metanoia (changing of the mind or thoughts). There is a point of contact, as Bavinck (1954) states, where religious sense crumbles and secularisation strikes. With it comes a sense of deep spiritual poverty, emptiness and fear. People lose their delight in the certainties in life, such as luxury, career or sport. They become tired of their own gods. In such situations, when resistance against the living God is broken, He gives meaning to our human existence. ${ }^{12}$

\section{Conclusion \\ Under the obedience of Christ Jesus}

The reason that I believe and work for the church is because the Spirit is there. Many of our fellow workers feel a certain weariness when they think of the institutional church. It's not that they have problems with God, but they have problems with the exclusive expression that Jesus is the only way to God the Father. The exclusivity of an absolute truth is questioned by many. We acknowledge and accept the fragmentation and pluralism of our society, but not the message and the consistency of the Bible.

We can see very clearly that attention has shifted from revelation to the experience of men. We live in a culture where people want to decide for themselves. The consequence of this thinking is the belief that, in the context of talking about the Spirit, they need to be addressed personally. They require a direct relationship with the Spirit. Their beliefs are based on what they believe the Spirit has told them (Van de Beek 1987:17). Do we not need a reorientation towards revelation and experience? Perhaps more credit needs to be given to the pietistic approach, where revelation and experience have always worked together

We can claim that this growing need for experience bears with it the danger that the Word of God and his promises will be forgotten. However, we have to acknowledge that for the believing person hearing from God is inherent in Protestantism. Especially in the Calvinistic tradition, the emphasis is on the work of the Spirit. Apart from all the outward observances, internal work for the believer is essential. The Spirit is the internal Teacher.

The personal dimension of our faith is that God speaks and we as human beings respond to Him in belief and trust focusing on God and on Jesus Christ. When we reject this aspect, namely that belief is not anchored in the knowledge of God but only in feeling, then we are where Schleiermacher began. ${ }^{13}$

12.The Spirit makes us 'tot machtigen in Christus.' In this case the Word of God is working, giving direction and freedom. Where this takes place, metanoia (conversion) occurs (Bavinck 1954).

13.For Schleiermacher (1830:3) the core of belief was anchored in feeling. 'Die Frömmigkeit, welche die Basis aller kirchlichen Gemeinschaften ausmacht, ist rein für sich betrachtet weder ein Willen noch ein Thun, sondern eine Bestimmtheit des Gefühls oder des unmittelbaren Selbstbewusstseins.'
The church is an outsider in this world because we focus on the Cross, or even more forcefully, because the Cross is the attraction (Carmichael 2005:47). The preaching of the crucified Christ and prayer is for the interweaving of God's regenerating spirit, that means the Spirit uses both, they work together, to have our eyes fixed on the crucified Christ. I believe that the message of the crucified Christ can be proof against all possible hindrances and is designed for all phases of history, even to the most obstinate.

However, results ultimately depend on the Holy Spirit. It is the Holy Spirit who convicts 'the world of guilt in regard to sin and righteousness and judgment' (Jn 16:8). He leads people to repentance, forgiveness and the reconciliation of all things to God in Christ. It is especially important to emphasise this in an era when we are tempted to replace the Holy Spirit with human ingenuity, strategies and technology.

Ultimately, it is all about God. We have to stand our ground against the enemy. At times this will involve encounters with the demonic, but typically it involves walking in the light of God's truth and prayerfully standing firm when the enemy does attack. One word should be added in conclusion. It is in such a time as this that the church has to proceed in humility, service, integrity, openness, prophetically and in devotion (cf. Eph 4:12). In this way we connect with the depth and broadness of the gospel today. I wonder if anything is more needed for the Christian mission work in this modern age than the healthy fusion of humility and humanity in our reliance on the power of the Holy Spirit (Stott quoted in Watson 1978:177). We desperately need the Spirit or we will fall prey to the world. We need to live our Christian life with God as the 'gekènde presentie' [known presence] (Bavinck n.d.:12). ${ }^{14}$ We have seen beauty, we now need to battle in order not to lose what we have seen.

\section{Acknowledgements Competing interests}

The author declares that he has no financial or personal relationship(s) which may have inappropriately influenced him in writing this article.

\section{References}

Anon, 2009a, 'De Veenhartkerk begon opnieuw', CV Koers, 64, Apr.

Anon, 2009b, 'Het calvinisme is weer hip', CV Koers, 73, Jun.

Anon, 2009c, 'Even black rappers who sing, The five points of Calvinism, are present', CV Koers, 73, Jun.

Balke, W., 1985, Gunning en Hoedemaker: Samen op weg, Boekencentrum, 's-Gravenhage.

Bavinck, J.H., n.d., Ik geloof in de Heilige Geest, Voorhoeve, Den Haag.

Bavinck, J.H., 1949, Religieus besef en christelijk geloof, Kok, Kampen.

Bavinck, J.H., 1954, Inleiding in de zendingswetenschap, Kok Kampen.

Benedetto, R., Guder, D.L. \& Mc Kim, D.K., 1999, Historical Dictionary of Reformed Churches: Historical Dictionaries of Religions, Philosophies and Movements, vol. 24, The Scarecrow Press, Lanham.

Bruce, F.F, 1981, The message of the New Testament, Paternoster, Exeter.

14. Bavinck's expression reminds us of the words of B. B. Warfield: 'A Calvinist is a man who has seen God' (Martin 1997:9). 
Carmichael, A., 2005, God's missionary, Dohnavur Fellowship, Fort Washington.

De Korte, G.J.N., 2009, 'Who is hindering us to be proud on our church, the bride of Christ?', CV Koers, 57, May.

Douma, J., 2000, Veni Creator Spiritus: De meditatie in het preekproces, Kok, Kampen.

Gnanakan, K., 2008, 'To proclaim the Good News of the Kingdom', in A. Walls \& C. Ross (eds.), Mission in the 21st century: Exploring the five marks of global mission, vol. 1, p.9, Longman, London.

Martin, A.N., 1997, The practical implications of Calvinism, The Banner of Truth Trust, Edingburgh.

Noordegraaf, A., 2009, Gedaanten van de Geest: Over de Persoon en het werk van de Heilige Geest, IZB, Amersfoort.

Pierson, A.T., 1913, The Acts of the Holy Spirit, 1st edn., Morgan and Scott, London.

Plaisir, B., 2008, 'Holy Spirit, renew your church', Groei, tijdschrift voor geestelijke vorming en missionaire gemeenteopbouw, 3,74
Protestantse Kerk in Nederland, 2003, Kerkorde en ordinanties van de Protestantse Kerk in Nederland inclusief de overgangsbepalingen, Boekencentrum, Zoetermeer.

Schleiermacher, F., 1830, Der christliche Glaube: Nach den Grundsätzen der Evangelischen Kirche im Zusammenhange Dargestellt, Reimer, Berlin.

Scott Moreau, A., Corwin, G.R. \& McGee, G.B. (eds.), 2004, Introducing world missions, Baker Academic, Grand Rapids.

Van de Beek, A., 1987, De adem Gods, De Heilige Geest in Kerk en Kosmos, G.F. Callenbach, Nijkerk.

Van de Kamp, W \& Tan, J. (eds.), 2009, Wij kiezen voor eenheid, Cross Light, Aalten.

Van der Walt, J.L., 2009, 'Spirituality: The new religion of our time', In die Skriflig 43(2), 251-269.

Van Eck, J., 2003, Handelingen: De wereld in geding, Kok, Kampen. (Commentaar op het Nieuwe Testament)

Van Ruler, A.A., 1972, Theologisch werk, deel 4, Nijkerk, Callenbach.

Watson, D., 1978, I believe in Evangelism, Hodder \& Stoughton, Sevenoaks. 